\author{
В.М. Турчин*, О.С. Лоскутов**, О.Ю. Савинська* \\ *Дніпровський національний університет імені Олеся Гончара \\ **Дніпровська медична академія МОЗ України
}

\title{
ЩОДО ОПТИМАЛЬНОГО ВИБОРУ ІМПЛАНТАТУ КУЛЬШОВОГО СУГЛОБА
}

У роботі запропоновано алгоритм вибору майже оптимального імплантату кульшового суглоба за кількісними характеристиками.

Ключові слова: алгоритм, вибірка, імплантат, кульшовий суглоб, кількісні характеристики.

\author{
V.M. Turchyn*, O.E. Loskutov**, O.Y. Savynska* \\ *Oles Honchar Dnipro National University \\ **Dnipropetrovsk Medical Academy of the Ministry of Health of Ukraine
}

\section{OPTIMAL CHOICE OF HIP IMPLANT}

Endoprosthetics often is almost the only solution for a patient with severe hip joint pathology. An important stage of a successful replacement is the adequate choice of an implant.

During installation of a hip implant one of its parts (so-called stem) is inserted in the femoral marrow cavity. Moreover, the installation must be done so that, on the one hand, the stem fits tightly, and, on the other hand, no critical stress appears in the cavity. Otherwise, serious postoperative complications are possible. Proper fit of the prosthesis is ensured by the correct choice from a given standard set of implants. At present one of traditional methods of implant choice is based on $\mathrm{X}$-ray images of the cavity in the AP projection and the lateral projection.

$X$-ray images of an implant are sequentially overlaid atop the thighbone images in the AP projection and the lateral projection and thus a suitable implant is selected. So the problem of devising an algorithm for choice of an implant based on quantitative characteristics emerges.

In order to solve the problem of optimal implant choice at first implants that fit in the cavity in the thirteenth knot, in the AP projection and the lateral projection are considered. The set of all such implants is called the set of admissible implants for a given cavity. We introduce a quantitative characteristics of tightness of implant fit against the walls of the cavity in the AP projection as the mean $L^{u, v}$ difference of the distance between the walls of the cavity $u$ and the walls of implant $v$ and also a quantitative characteristics of tightness of implant fit against the walls of the cavity in the lateral projection as the minimal distance $f_{u, v}$ between the front wall of the cavity $u$ and the front wall of the implant $v$.

The optimal implant with respect to the AP projection is the one for which $L^{u, v}$ reaches its minimal value and the optimal implant with respect to the lateral projection is the one for which $f_{u, v}$ reaches its minimum. Generally speaking, the measures $L^{u, v}$ and $f_{u, v}$ are reached at different implants, therefore one can speak only about a nearly optimal implant.

(C) Турчин В.М., Лоскутов О.Є., Савинська О.Ю., 2020 
Keywords: algorithm, sample, implant, hip joint, quantitative characteristics.

\author{
В.Н. Турчин*, А.Е. Лоскутов**, Е.Ю. Савинская* \\ *Днипровский начиональный университет имени Олеся Гончара \\ **Днепровская медииинская академия МОЗ Украинь
}

\title{
ОПТИМАЛЬНЫЙ ВЫБОР ИМПЛАНТАТА ТАЗОБЕДРЕННОГО СУСТАВА
}

В работе предложен алгоритм выбора почти оптимального имплантата тазобедренного сустава по количественным характеристикам.

Ключевые слова: алгоритм, выборка, имплантат, тазобедренный сустав, количественные характеристики.

Вступ. Для хворого з тяжкою патологією кульшового суглоба чи не єдиним виходом $\epsilon$ ендопротезування.

Під час встановлення імплантату (див. рис. 1 та рис. 2) кульшового суглоба його однією частиною - ніжкою, садять у кістково-мозковий канал стегнової кістки (див. рис. 3 та рис. 4). Причому це потрібно зробити так щоб, з одного боку, ніжка щільно прилягала до стінок каналу, а з іншого, у каналі не повинно виникати критичних напружень. У супротивному разі можливі серйозні післяопераційні ускладнення. Належне прилягання імплантату до стінок каналу забезпечується оптимальним вибором імплантату із заданого стандартного набору імплантатів. На сьогоднішній день вибір імплантату реалізують за рентгенівськими знімками каналу у прямій та бічній проекціях: послідовно накладаючи на знімки кульшового суглоба і стегнової кістки у прямій та бічній проекціях креслення імплантатів виконаних на прозорій плівці, вибрають оптимальний імплантат.

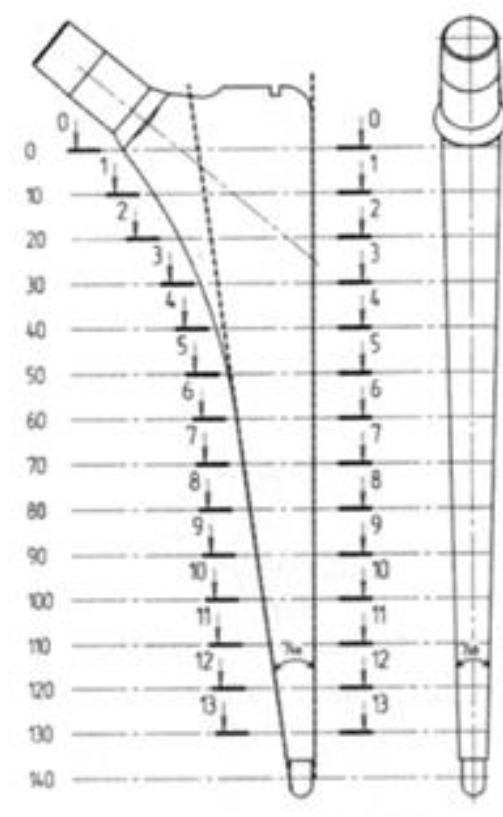

Рис. 1. Імплантат ЗК-6 у прямій та бічній проекціях

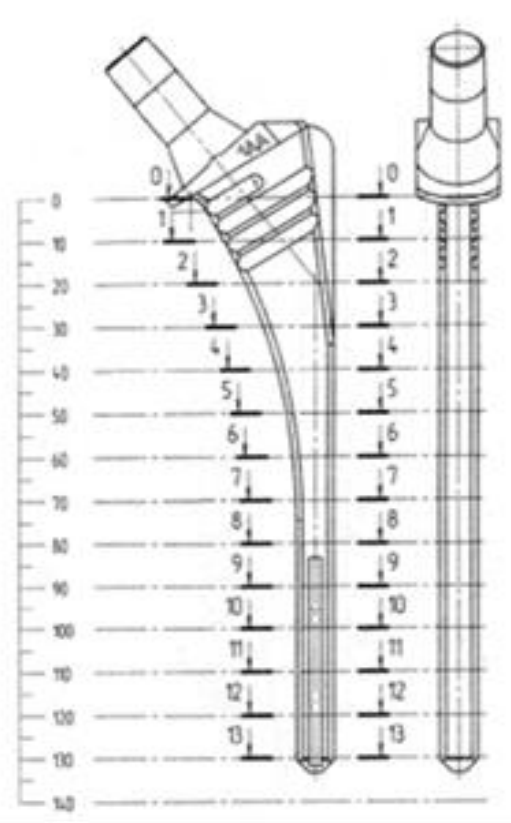

Рис. 2. Імплантат ДД-1 у прямій та бічній проекціях 
У зв'язку з цим виникає задача побудови критерію та алгоритму вибору оптимального імплантату за кількісними характеристиками каналу.

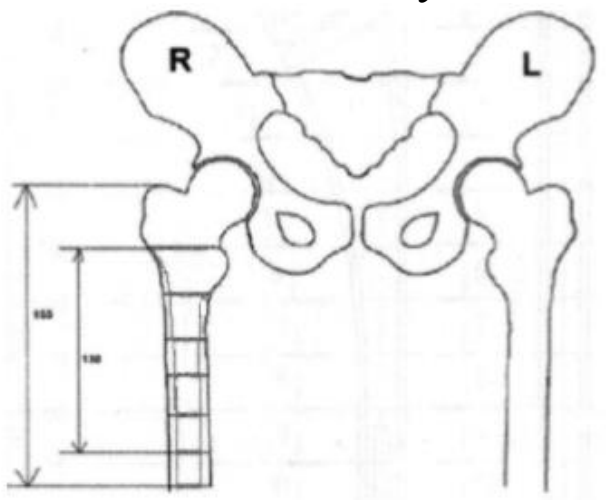

Рис. 3. Кульшовий суглоб і кістковомозковий канал у прямій проекції

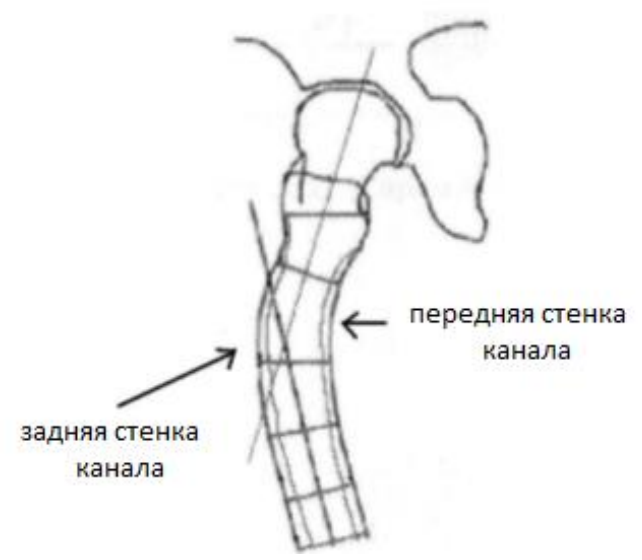

Рис. 4. Кульшовий суглоб і кістковомозковий канал у бічній проекції

Постановка задачі. Запропонувати критерій і алгоритм вибору оптимального імплантату для даного каналу за його кількісними характеристиками (алгоритм вибору імплантату окремо у прямій проекції розглядався у [1], у бічній - у [2]).

Вихідними даними є оцифровані рентгенівські знімки каналу стегнової кістки. 3 кроком 11.5 мм у 13-ти вузлах знімалися заміри $a_{i}$ ширини каналу у прямій проекції (див. рис. 5) та $b_{i}$ у бічній (див. рис. 6), у бічній додатково вимірюється кут викривлення каналу $\alpha$ та відстань $l_{\alpha}$ від початку каналу до вершини кута викривлення (див. рис. 7). Обсяг вибірки дорівнює 133.

Пряма і бічна проекції каналу та імплантату. Осьовий переріз каналу зі встановленим імплантатом у прямій проекції мають вигляд зображений на рис. 5. На рис. 5 тонкою лінією зображено стінки каналу, жирною лінією стінки імплантату.

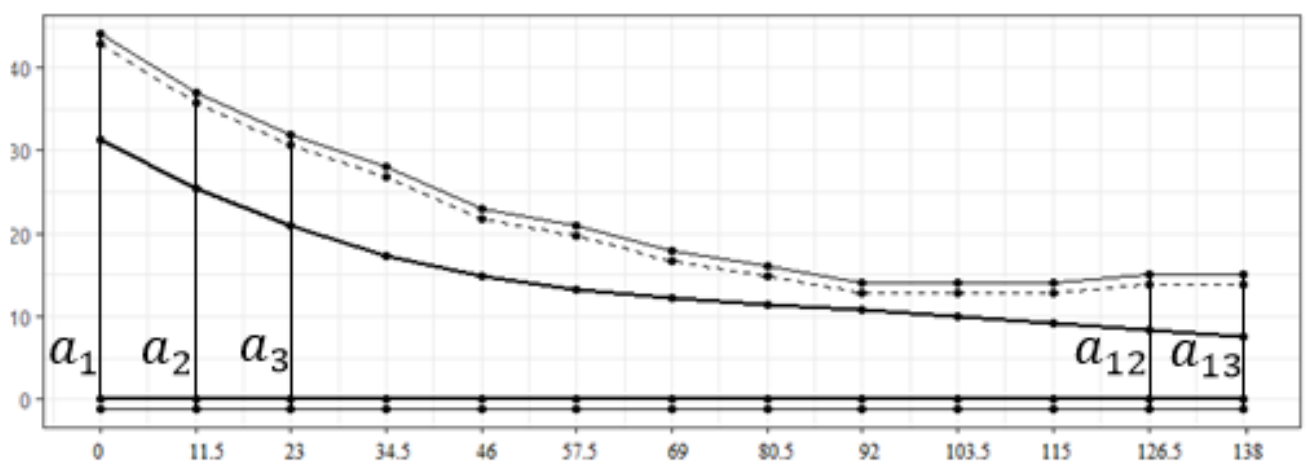

Рис. 5. Пряма проекція каналу зі встановленим імплантатом

Бічна проекція каналу за його числовими характеристиками: $b_{j}-$ шириною каналу у $j$-му вузлі $x_{j}, j=1,2, \ldots, 13$, кутом $\alpha$ викривлення каналу і відстанню $l_{\alpha}$ від початку каналу до вершини кута викривлення будується так. У си- 
стемі координат $O x y$ будуємо точки $x_{j}, y_{j}, y_{j}=b_{j}^{k} / 2, j=1,2, \ldots, 13$, i 3’єднуємо їх ламаною (див. рис. 6). Ще одну ламану отримаємо, з'єднавши точки $x_{j},-y_{j}$. Ці дві ламані можна розглядати як проекцію каналу, коли $\alpha=0$ (див. рис. 6). Поворотом на кут $\alpha$ навколо точки $l_{\alpha}$ отримаємо бічну проекцію каналу (див. рис. 7.). Поворот реалізується перетворенням

$$
\begin{gathered}
x^{\prime}=x-l_{\alpha} \cos \alpha-y \sin \alpha+l_{\alpha}, \\
y^{\prime}=x-l_{\alpha} \sin \alpha+y \cos \alpha .
\end{gathered}
$$

Положення імплантату у бічній проекції визначається положенням його задньої стінки відносно задньої стінки каналу (див. рис. 7).

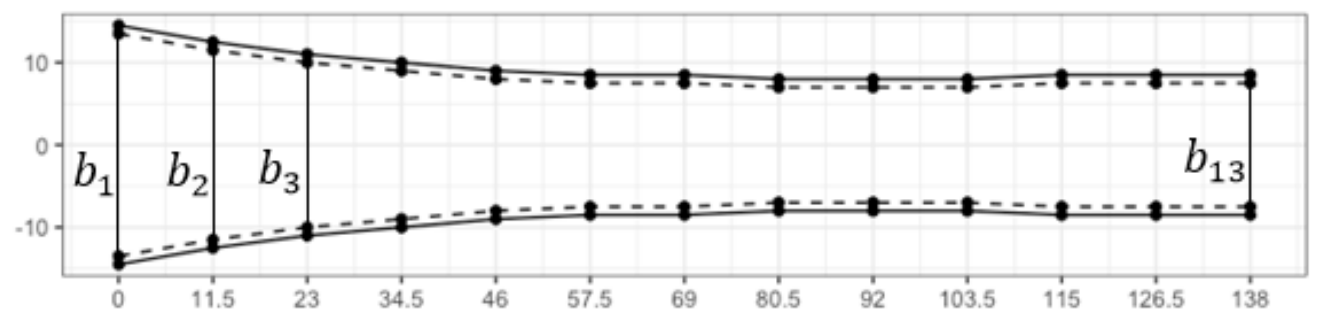

Рис. 6. Бічна проекція каналу при $\alpha=0$

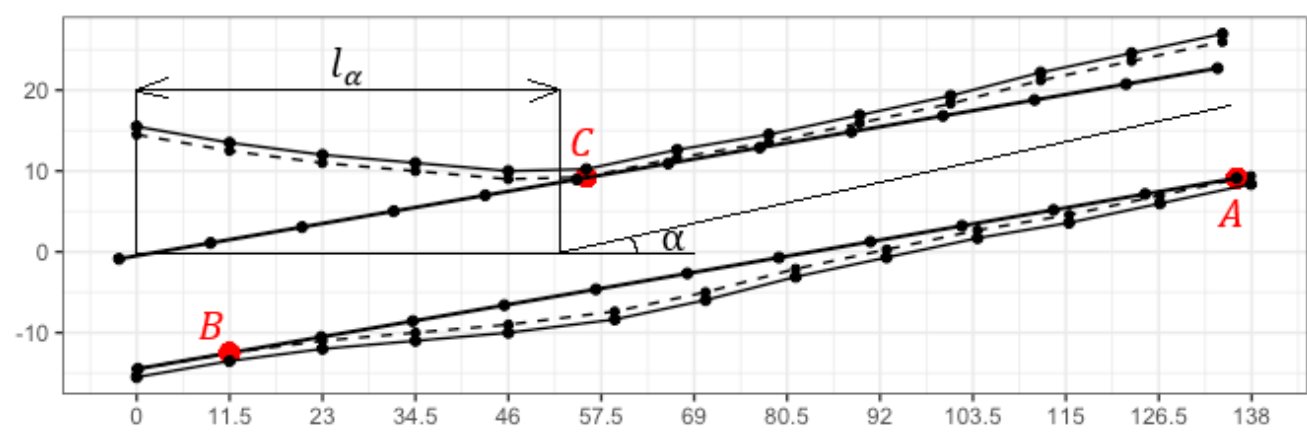

Рис. 7. Бічна проекція каналу та імплантату

Необхідна умова входження імплантату у канал у 13-му вузлі. Переріз каналу, ортогональний його вісі, залежить від точки перерізу і має форму овалу

$$
\frac{|x|^{\gamma}}{a^{\gamma}}+\frac{|y|^{\gamma}}{b^{\gamma}}=1 \quad \gamma>1
$$

При $\gamma=2$ овал співпадає 3 еліпсом 3 напівосями $a, b$. Значення оцінки (див. [4]) параметра $\gamma$ отриманого за вибіркою перерізів каналів у 13-му вузлі дорівнює 2.5, тому можна вважати, що у 13-му вузлі переріз каналу має форму овалу з параметром 2.5 :

$$
\frac{|x|^{2.5}}{\left(a^{k}\right)^{2.5}}+\frac{|y|^{2.5}}{\left(b^{k}\right)^{2.5}}=1,
$$


де $a^{k}=a_{u, 13}^{k} / 2, b^{k}=b_{u, 13}^{k} / 2 ; \quad a_{u, 1}^{k}$-ширина $u$-го каналу у 13-му вузлі прямій проекції, $b_{u, 13}^{k}-$ у бічній $(u=1,2,3, \ldots, 133)$.

На рис. 8 і рис. 9 зображено перерізи каналу та імплантатів у 13-му вузлі.

Величина $\varepsilon^{u, v}$. Через викривлення каналу у бічній проекції, імплантат може дотикатися до стінок каналу (у бічній проекції) не більше ніж у 3-х точках. У ідеальній ситуації імплантат дотикається каналу у трьох точках (див. рис. 7).

Якщо імплантат дотикається каналу у 3-х точках, переріз каналу та імплантату у 13-му вузлі має вигляд зображений на рис. 10. Імплантат дотикається стінок каналу ребрами, тому між стінками каналу та стінками імплантату спостерігається просвіт, який для $u$-го каналу та $v$-го імплантату позначимо через $\varepsilon^{u, v}$ (див. рис. 10).

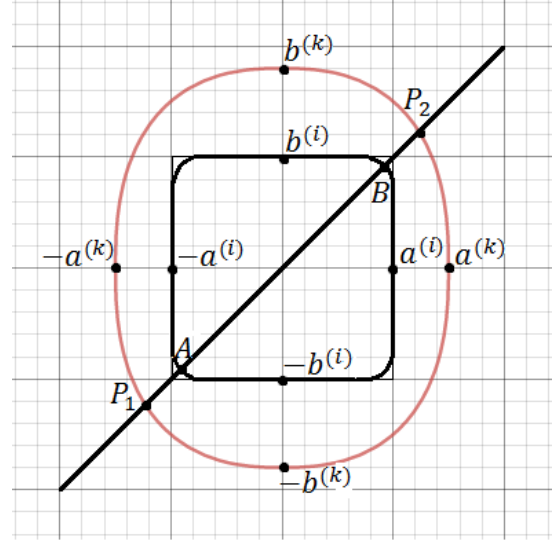

Рис. 8. Переріз каналу та імплантату у 13-му вузлі $\left(A B<P_{1} P_{2}\right)$

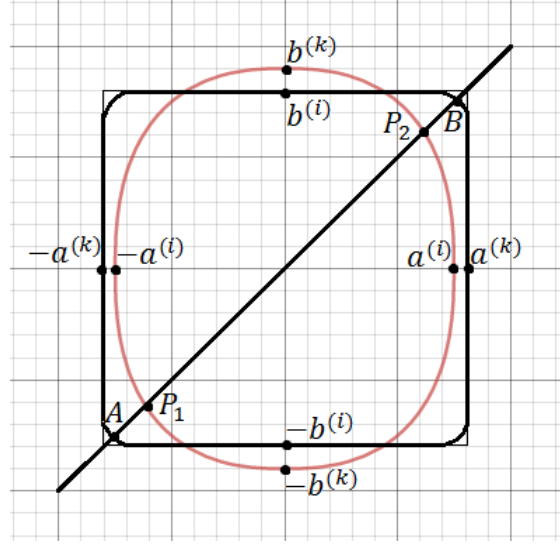

Рис. 9. Переріз каналу та імплантату у 13-му вузлі $\left(A B>P_{1} P_{2}\right)$

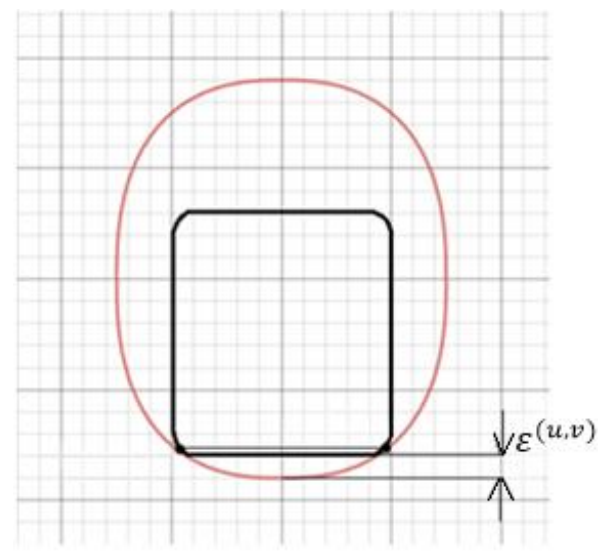

Рис. 10. Перетин каналу та імплантату у 13-му вузлі

Для $u$-го каналу та $v$-го імплантату за значеннями $a^{k}, b^{k}$ ширини каналу у прямій та бічній проекціях відповідно, та за значеннями $a^{i}, b^{i}$ ширини імплантату у прямій та бічній проекціях, завжди можна обчислити $\varepsilon^{u, v}$. Значення $\varepsilon^{u, v}$ своє для кожної пари канал-імплантат. Будемо вважати, що вели- 
чина просвіту між імплантатом і каналом у тих вузлах, де імплантат дотикається до стінок каналу, така сама як і у 13-му вузлі, тобто $\varepsilon^{u, v}$.

Допустимі границі розташування імплантату у каналі у прямій проек ції. На рис. 5 штриховими лініями зображені допустимі границі розташування імплантату у каналі у прямій проекції. Допустимі границі розташування імплантату у каналі у прямій проекції отримуємо "зсувом стінок каналу" всередину каналу вздовж осі ординат на величину $\varepsilon^{u, v}$. Зауважимо, що "нижня" допустима границя у прямій проекції збігається 3 "нижньою” стінкою імплантату, що лежить на вісі абсцис.

Допустимі границі розташування імплантату у каналі у бічній проекціï. На рис. 6 штриховими лініями зображені допустимі границі розташування імплантату у каналі у бічній проекції, коли $\alpha=0$. Допустимі границі розташування імплантату у каналі у бічній проекції отримаємо ,зсувом стінок каналу" без викривлення на величину $\varepsilon^{u, v}$ всередину каналу вздовж осі $O y$, а потім поворотом на кут $\alpha$ навколо точки $\left(l_{\alpha}, 0\right)$ (див. рис. 7).

У бічній проекції оптимальний імплантат дотикається стінок каналу у 3-х точках (див. рис. 7), $A, B, C$-проекції точок, у яких імплантат дотикається стінок каналу ( $A, B$ - проекції точок дотику до задньої стінки).

Положення задньої стінки імплантату, точніше іiі проекції, - відрізка $a$ довжиною 138 мм, відносно проекції задньої стінки каналу, визначається так. Один кінець відрізка $a$ - точка $A$ (див. рис. 7) лежить на лінії регресії, побудованої за вузлами допустимої границі задньої стінки каналу (після кута викривлення), другий кінець відрізка $a$ знаходиться на прямій $x=0$, відрізок $a$ проходить через один із вузлів допустимої границі задньої стінки до кута викривлення (вузол $B$, див. рис. 7) каналу так, що всі вузли до кута викривлення лежать “нижче” відрізка $a$ (див. рис. 7).

Необхідні умови входження імплантату у канал у прямій проекції. Необхідною умовою входження $v$-го імплантату у $u$-й канал у прямій проекції $є$

$$
a_{u, j}^{k}-2 \varepsilon^{u, v} \geq a_{v, j}^{i}, \quad j=1,2, \ldots, 13
$$

$u$ - номер каналу, $v$ - номер імплантату, $a_{u, j}^{k}-$ ширина $u$-го каналу у $j$-му вузлі, $a_{v, j}^{i}-$ ширина $v$-го імплантату у $j$-му вузлі.

Умова (2) для кожного каналу задає набір імплантатів, які можуть входити до каналу у прямій проекції і з яких вибирається оптимальний імплантат. Зокрема набір імплантатів, що входить до даного каналу може бути і порожньою множиною (жоден імплантат не входить у канал).

Необхідні умови входження імплантату у канал у бічній проекції. Обчислюємо мінімальну відстань від допустимої границі передньої стінки каналу до задньої стінки імплантату, позначимо їі через $d_{u}$. Очевидно

$$
d_{u}=\min _{j} l_{j}, \quad l_{j}=\frac{\left|a x_{j}+b y_{j}+c\right|}{\sqrt{a^{2}+b^{2}}}, j=1,2, \ldots, 13,
$$


де $a x+b y+c=0$ - рівняння прямої, на якій лежить відрізок $A B, \mathrm{a}\left(x_{j}, y_{j}\right)-$ точка, що лежить на допустимій границі передньої стінки каналу.

Далі обчислюємо $d_{v}{ }^{i}$-ширину імплантату $v$ у точці, де $l_{j}, j=1,2, \ldots, 13$, досягає свого найменшого значення $d_{u}$.

Необхідною умовою входження імплантату у канал у бічній проекції буде умова: ширина $d_{u, v}^{i}$ імплантату $v$ при фіксованому $u$ не перевищує значення $d_{u}$, тобто

$$
d_{u, v}^{i} \leq d_{u} .
$$

Множину імплантатів, які задовольняють необхідні умови 1,2 і 4 будемо називати допустимою для даного каналу $u$.

Характеристики щільності прилягання імплантату до стінок каналу у прямій проекції. Далі пропонуються кількісні характеристики щільності прилягання імплантату до стінок каналу у прямій проекції та співвідношення між ними.

Характеристика $S^{u, v}$ означається рівністю

$$
S^{u, v}=\frac{h}{2} \sum_{j=1}^{n-1} a_{u, j}^{k}-a_{v, j}^{i}+a_{u, j+1}^{k}-a_{v, j+1}^{i} .
$$

Значення $S^{u, v}$ чисельно дорівнює площі зафарбованої фігури зображеної на рис. 11 , тут $n=13, h=11.5$ мм (див. також [1]).

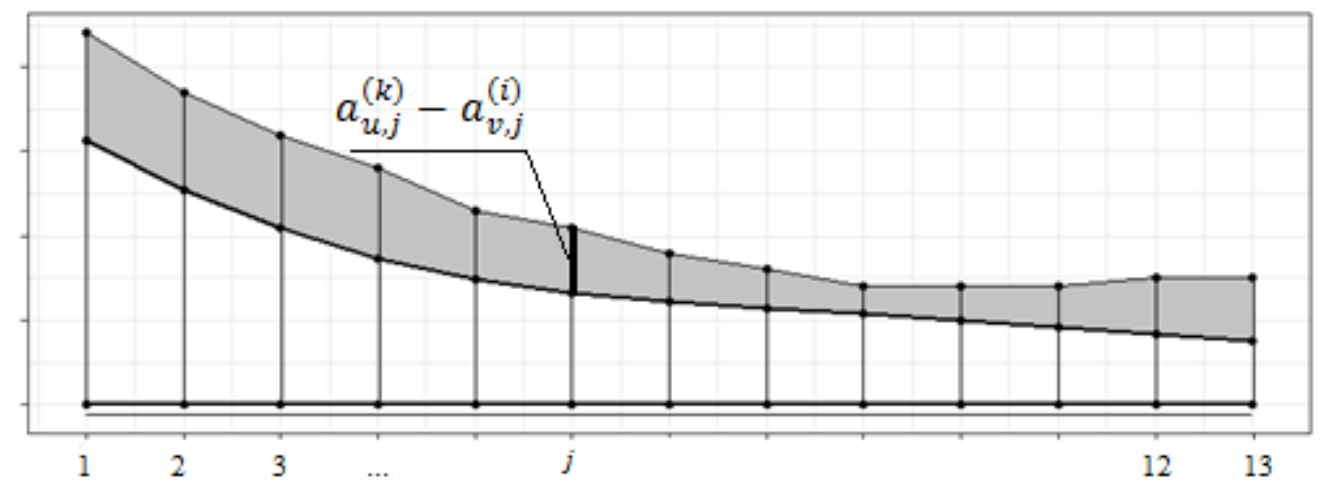

Рис. 11. До означення характеристики $S^{u, v}$

Характеристика $L^{u, v}$ означається рівністю

$$
L^{u, v}=\frac{1}{n} \sum_{j=1}^{n} a_{u, j}^{k}-a_{v, j}^{i}
$$

Чисельне значення характеристики $L^{u, v}$ дорівнює середньому значенню довжин відрізків $a_{u, j}^{k}-a_{v, j}^{i}, j=1,2, \ldots, n$ (див. також рис. 11).

Характеристику $L^{u, v}$ можна також подати у вигляді 


$$
L^{u, v}=\frac{1}{n} \sum_{j=1}^{n} a_{u, j}^{k}-a_{v, j}^{i}=\frac{1}{n h} \sum_{j=1}^{n} h a_{u, j}^{k}-a_{v, j}^{i}=\frac{1}{n h} S_{s}^{u \cdot v},
$$

де

$$
S_{s}^{u . v}=\sum_{j=1}^{n} h a_{u, j}^{k}-a_{v, j}^{i},
$$

а $n h$-довжина імплантату, тобто

$$
L_{a}^{k, i}=\frac{1}{n h} S_{s}^{u . v} .
$$

Чисельно $S_{s}^{u . v}$ дорівнює площі зафарбованої фігури, зображеної на рис. 12. Останній доданок $h a_{u, 13}^{k}-a_{v, 13}^{i}$ у сумі $S_{s}^{u . v}$ суттєво залежить від величини $a_{u, 13}^{k}-a_{v, 13}^{i}$. Тому характеристика $S_{s}^{u \cdot v}$ більш „чуттєво реагує” на значення величини $a_{u, 13}^{k}-a_{v, 13}^{i}$, ніж характеристика $S^{u, v}$. Саму величину $a_{u, 13}^{k}-a_{v, 13}^{i}$ природно розглядати як кількісну характеристику фіксації імплантату у 13 -му вузлі.

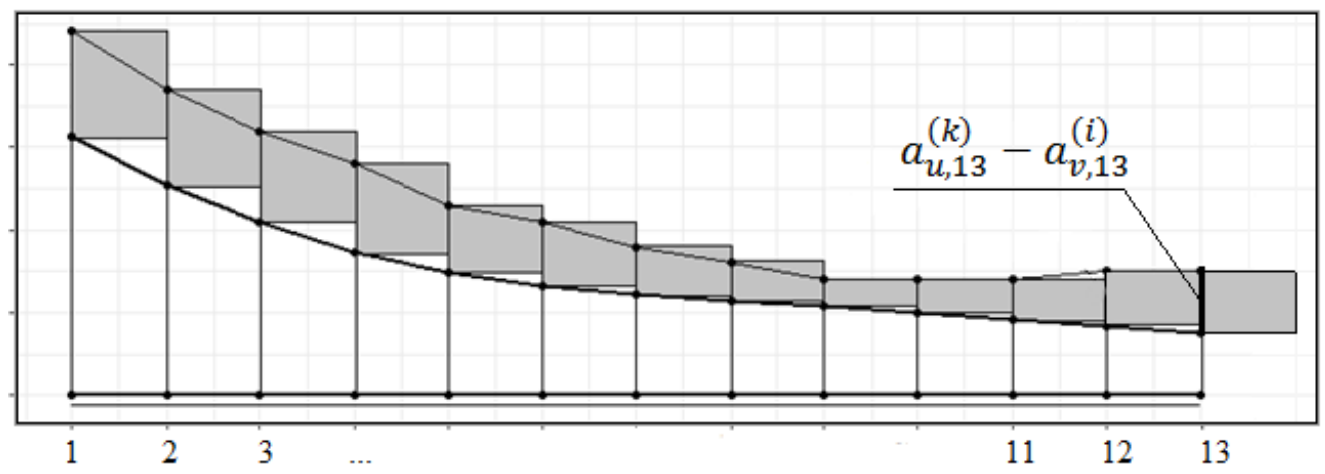

Рис. 12. До означення характеристики $L^{u, v}$

Характеристика $m^{u, v}$ означається рівністю

$$
m^{u, v}=\max _{1 \leq j \leq n} a_{u, j}^{k}-a_{v, j}^{i} .
$$

Зазначимо, що значення характеристики $m^{u, v}$ визначається значенням $a_{u, j}^{k}-a_{v, j}^{i} \quad$ у точці $j_{0}$, де $a_{u, j}^{k}-a_{v, j}^{i}$ досягає найбільшого значення

$$
a_{u, j_{0}}^{k}-a_{v, j_{0}}^{i}=\max _{1 \leq j \leq n} a_{u, j}^{k}-a_{v, j}^{i} .
$$

При цьому значення $a_{u, j}^{k}-a_{v, j}^{i}$ у точках $j \neq j_{0}$, коли $a_{u, j}^{k}-a_{v, j}^{i}<a_{u, j_{0}}^{k}-a_{v, j_{0}}^{i}$ на $m^{u, v}$ не впливають, але ці значення входять у $L^{u, v}, S^{u, v}$, а отже впливають на ці величини. Тому природно, що характеристики $L^{u, v}, S^{u, v}$ „чуттєвіші” як 170 
числові характеристики щільності прилягання імплантату до стінок каналу ніж $m^{u, v}$.

Виходячи зі сказаного, далі у якості числової характеристики щільності прилягання імплантату до стінок каналу у прямій проекції будемо розглядати величину $L^{u, v}$.

Характеристика щільності прилягання імплантату до стінок каналу у бічній проекції. Оптимальним імплантатом у бічній проекції із заданого набору буде той, для якого мінімальна відстань між допустимою границею передньої стінки каналу і передньою стінкою імплантату є найменшою.

Щоб вибрати для даного каналу $u$ оптимальний у бічній проекції імплантат, спочатку обчислюємо мінімальну відстань $d_{u}$ від допустимої границі передньої стінки каналу до задньої стінки імплантату (див. (3)).

Далі обчислюємо ширину $d_{v}{ }^{i}$-ширину імплантату $v$ у точці, де $l_{j}$, $j=1,2, \ldots, 13$, досягає свого найменшого значення $d_{u}$ і вибираємо $з$ допустимих імплантатів як оптимальний для каналу $u$ той імплантат $v$, для якого ширина $d_{u, v}^{i}$ імплантату $v$ при фіксованому $u$ найбільша, тобто той, для якого

$$
d_{u, v}^{i}=\max _{v} d_{u, v}^{i},
$$

інакше кажучи, для якого величина $f_{u, v}=d_{u}-d_{u, v}^{i}$ є мінімальною (див. також [2]).

Щодо вибору оптимального імплантату за прямою та бічною проекціями. Для $u$-го каналу та кожного з допустимих імплантатів обчислюємо характеристики щільності прилягання $L^{u, v}$ та $f_{u, v}$ у прямій та бічній проекціях відповідно та відсортовуємо отримані значення характеристик у порядку зростання. Оптимальним імплантатом буде той, для якого характеристики $L^{u, v}$ та $f_{u, v}$ приймають мінімальні значення, але це не обов'язково досягається на одному і тому самому імплантаті. Тому ми будемо говорити про майже оптимальні імплантати як такі, для яких значення характеристик $L^{u, v}$ i $f_{u, v}$ за кожною проекцією близькі до мінімальних. При цьому остаточне рішення щодо вибору імплантату залишається за хірургом.

Приклад (канал №32). Розглянемо вибір імплантату для каналу №32. Зазначимо, що у канал № 32 було встановлено імплантат $v=2$ (ДД-2). Пряму проекцію каналу №32 та встановлений імплантат $v=2$ (ДД-2) зображено на рис. 13. Канал №32 та встановлений імплантат $v=2$ (ДД-2) у бічній проекції зображено на рис. 14. 


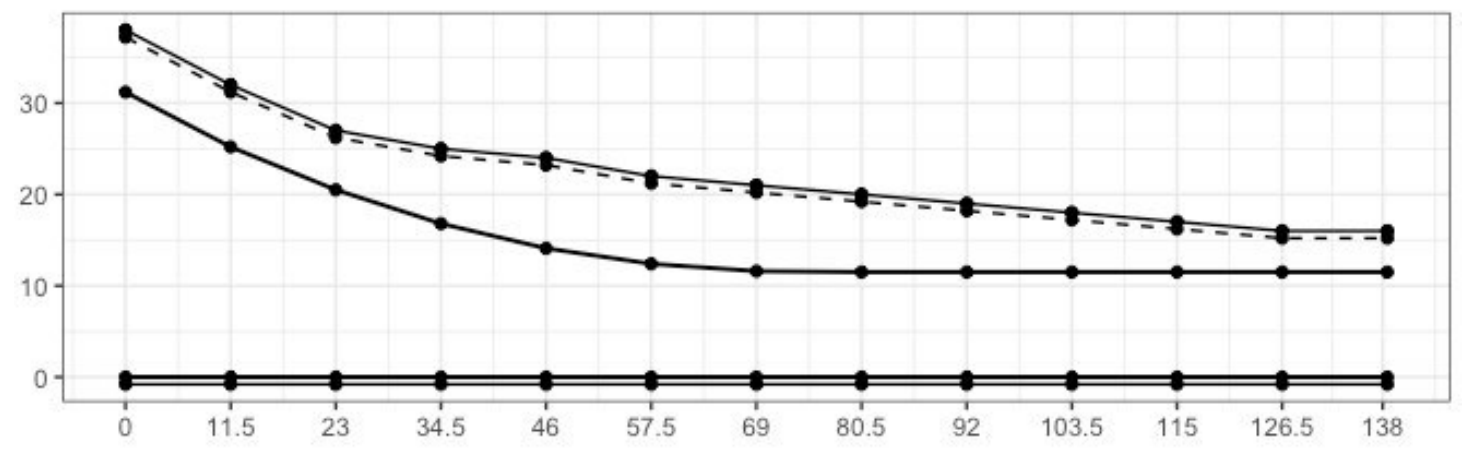

Рис. 13. Канал № 32 та встановлений імплантат $v=2$ (ДД-2) у прямій проекції

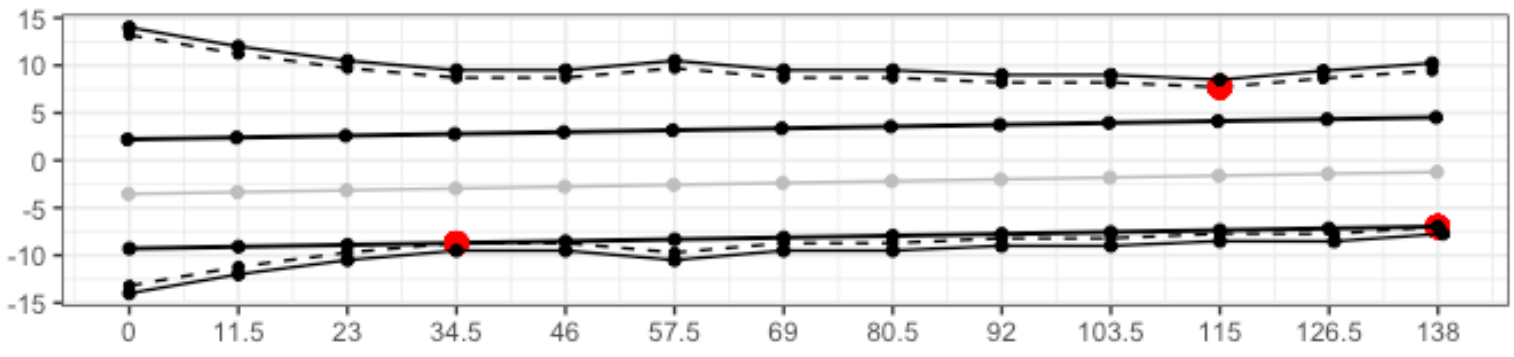

Рис. 14. Канал № 32 та встановлений імплантат $v=2$ (ДД-2) у бічній проекції

Щільність прилягання імплантату $v=2$ (ДД-2) до стінок каналу №32 залишає бажати кращого (див. рис. 13 та рис. 14). Зазначимо, що значення характеристик для встановленого імплантату $L^{32,2}=7.25 ; f_{32,2}=3.56$ (див. табл. 1).

Спробуємо для каналу №32 з множини допустимих імплантатів для каналу №32 підібрати імплантат, для якого значення $L^{32, v}$ та $f_{32, v}$ були б меншими.

У табл. 1. наведено номери $v$ допустимих імплантатів для каналу №32 та значення характеристик $L^{32, v}, f_{32, v}$ - щільності прилягання імплантату до стінок каналу № 32 у прямій та бічній проекціях. Характеристики $L^{32, v}$ та $f_{32, v}$ "відсортовані" за значеннями у порядку зростання.

Згідно $з$ табл. 1 імплантат $v=14$ (Д-3) видається майже оптимальним. Для імплантату $v=14$ (Д-3) значення $f_{32,14}=1.68$ мінімально можливе серед значень $f_{32, v}$, значення $L^{32,14}=5.72$ третє за величиною серед $L^{32, v}$.

У таблиці також виділені характеристики встановленого імплантату $v=2$ (ДД-2), для нього $L^{32,2}=7.25>5.72=L^{32,14}$ та $f_{32,2}=3.56>1.68=f_{32,14}$.

Канал № 32 з імплантатом $v=14$ (Д-3) зображено на рис. 15 (пряма проекція) та на рис. 16 (бічна проекція). 
Значення $L^{32, v}$ та $f_{32, v}$.

\begin{tabular}{|c|c|c|c|}
\hline $\boldsymbol{v}$ & $L^{(32, v)}$ & $v$ & $f_{32, v}$ \\
\hline 22 (ПК-4) & 3,60 & 3 (ДД-3) & 1,68 \\
\hline 21 (ПК-3) & 5,12 & $14(Д-3)$ & 1,68 \\
\hline 14 (Д-3) & 5,72 & 19 (ПК-1) & 2,80 \\
\hline 3 (ДД-3) & 6,11 & 2 (ДД-2) & 3,56 \\
\hline $9(3 K-4)$ & 6,29 & 13 (Д-2) & 3,56 \\
\hline 13 (Д-2) & 6,84 & 1 (ДД-1) & 5,15 \\
\hline 20 (ПК-2) & 6,86 & 12 (Д-1) & 5,15 \\
\hline 2 (ДД-2) & 7,25 & 20 (ПК-2) & 5,20 \\
\hline $8(3 K-3)$ & 7,85 & 21 (ПК-3) & 5,20 \\
\hline $12($ Д-1) & 7,92 & 22 (ПК-4) & 5,70 \\
\hline 1 (ДД-1) & 8,32 & $7(3 K-2)$ & 7,00 \\
\hline 19 (ПК-1) & 8,66 & $8(3 K-3)$ & 7,00 \\
\hline $7(3 K-2)$ & 9,62 & $9(3 K-4)$ & 7,50 \\
\hline $6(3 K-1)$ & 11,42 & $6(3 K-1)$ & 8,42 \\
\hline
\end{tabular}

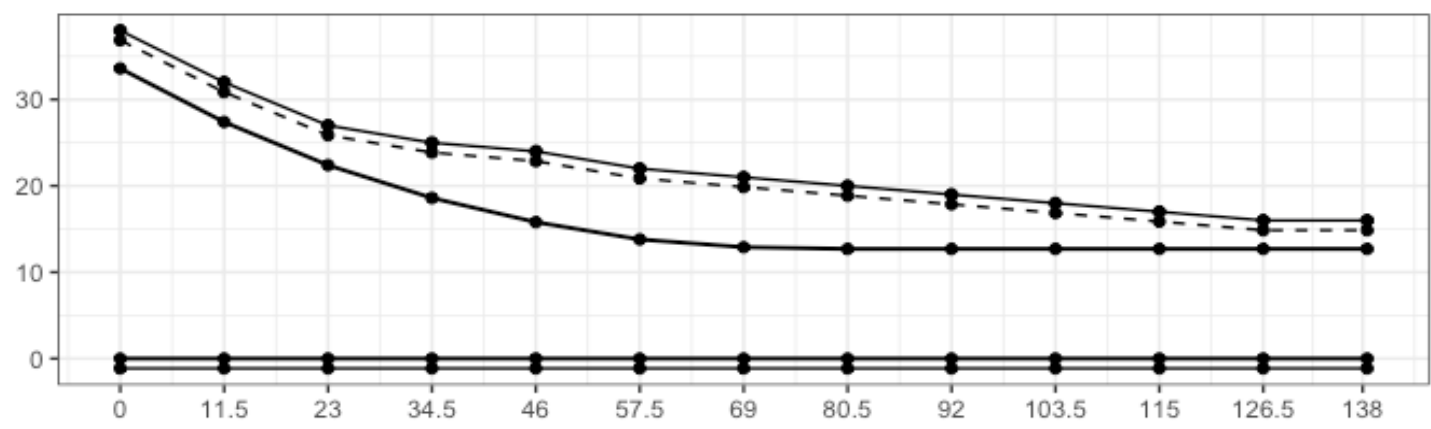

Рис. 15. Канал № 32 та рекомендований імплантат $v=14$ (Д-3) у прямій проекції

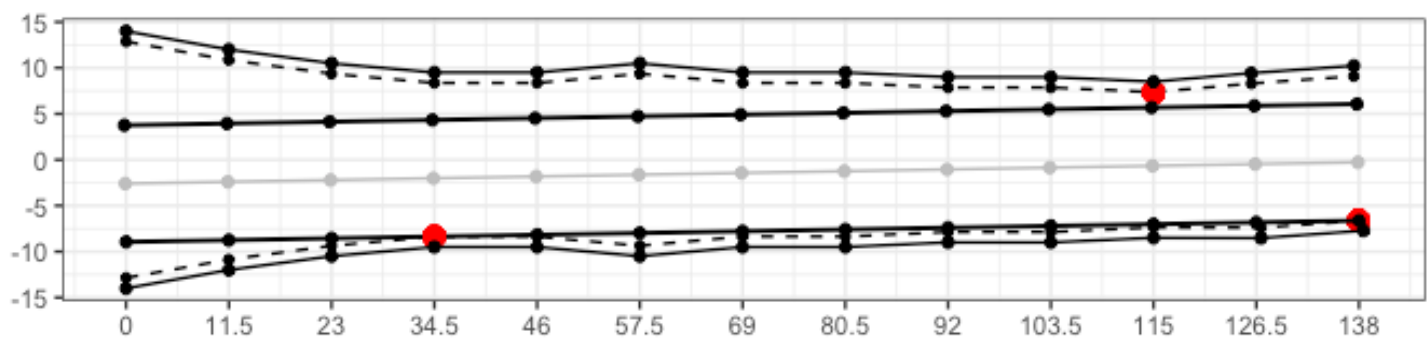

Рис. 16. Канал № 32 та рекомендований імплантат $v=14$ (Д-3) у бічній проекції 
Висновки. Запропоновано критерії вибору імплантату кульшового суглоба та алгоритм вибору оптимального імплантату для даного каналу із даного набору імплантатів.

\section{Бібліографічні посилання}

1. Лоскутов, А.Е. Питання оптимального вибору імплантату кульшового суглоба [Текст] / А.Е. Лоскутов, В.Н. Турчин, А.П. Дегтяренко, О.О. Лоскутов // Питання прикладної математики і математичного моделювання: зб. наук. пр. - 2016. - С. 91-101.

2. Турчин, В.Н. К проблеме выбора имплантата тазобедренного сустава [Текст] / В.Н. Турчин, О.А. Лоскутов, А.С. Дрожжин, Е.В. Волкова // Питання прикладної математики і математичного моделювання: зб. наук. пр. - 2016. - С.177-185.

3. Эндопротезирование тазобедренного сустава: Моногр. [Текст] / Под ред. проф. А.Е. Лоскутова. - Д., 2010. -344 с.

4. Турчин, В.Н. Теория вероятностей и математическая статистика $[$ Текст $] /$ В.Н. Турчин. - Д., 2018. $-752 \mathrm{c}$.

Надійшла до редколегії 22.09.2020. 